\title{
THE EFFECT OF RETURN ON ASSETS, FREE CASH FLOW, AND DEBT TO EQUITY RATIO ON COMPANY VALUE
}

\author{
Putri Renalita Sutra Tanjung \\ Universitas Mercu Buana, \\ Jakarta, \\ Indonesia
}

Article DOI: https://doi.org/10.36713/epra5329

\begin{abstract}
This research aims to empirically examine the effect of Return on Assets, Free Cash Flow, and Leverage on its value in the Consumer Goods Industry company during the year 2016 to 2018. The method of determining the sample uses purposive sampling. One hundred eighteen pieces were selected with predetermined criteria on this. This research's independent variables are Return On Assets, Free Cash Flow, and Leverage as the dependent variable is Company Value. The analysis technique used in this research is descriptive statistics, classic assumptions, feasibility models. The results indicate that the variable Return on assets and Leverage affect the company's value. Whereas the variable Free Cash Flow does not affect the value of the company.
\end{abstract}

KEYWORDS: Return On Assets, Free Cash Flow,Leverage and Company's value.

\section{INTRODUCTION}

The goal of a company is to maximize company value or wealth for shareholders. Maximizing company value is considered more appropriate as a company's goal because maximizing firm value means maximizing the present value of all profits that shareholders will receive in the future. Company Value is the selling value of a company as an operating business. An excess of selling value over the liquidation value is the value of the management organization that runs the company (Sartono, 2010).

High corporate value is company owners' desire because high values indicate that shareholders' prosperity is also increased (Hemastuti, 2014). According to Noerirawan (2012), company value is a condition that has been achieved by a company as a reflection of public trust in the company after going through a process of activity for several years, namely from the time the company was founded to the present.

Meanwhile, according to Husnan (2014), company value is the price a potential buyer can pay when the company is sold. When a company has been publicly listed or has offered shares to the public, its value is defined as an investor's perception of the company itself. Investors can use the company value as the basis for seeing the company's performance in the coming period, where company value is often associated with stock prices. Investors will benefit if the company's share price is high.

Good Return On Assets (ROA) can increase company value. This is because Return On Assets (ROA) is a ratio that shows the results of the total assets used in the company (Kasmir 2014). ROA is a profitability ratio used to measure the company's effectiveness in generating profits by utilizing its total assets. The greater the ROA, the higher the company's ability to provide benefits through assets owned by the company, this will help increase the value of a company.

In a study by Triagustina et al. (2015), it is stated that ROA has a significant negative effect on firm value. This is because management performance in managing company assets has not been maximized so that large investments can only generate small or less than optimal profits. In other research conducted by Astriani (2014) found that ROA does not have a significant effect on firm value, this is because the profits that companies get are unstable from year to year and tend to fluctuate so that investors are not 
sure what results in the company will get in the future.

The results of other studies show that profitability with the proxy of ROA shows that ROA has a positive effect on firm value. The greater the ROA, the more effective and efficient assets will increase firm value (Widiastari and Yasa, 2018). The results of this study are also supported by other researchers Chen and Chen (2011), Pratama (2016), and Garmayuni (2015). They also state that ROA has a positive effect on firm value because the higher the ROA value, the company's ability to pay dividends will also be higher. This will increase investor confidence in a company that can affect company value.

Company value can also be affected by Free Cash Flow (FCF). This is because Free Cash Flow (FCF) is a measure of growth, financial performance, and company health. Free Cash Flow represents the remaining cash from business operating activities that can be used for dividend payments, expansion, or debt repayment. The more Free Cash Flow value the company prints, the better. According to Brigham and Houston (2014), free cash flow is the cash flow available to investors (shareholders and debt owners) after the company has invested in fixed assets, new products, and working capital needed to maintain ongoing operations.

High free cash flow will impact increasing company value, which is indicated by high company performance so that the company's stock price becomes high (Arfan, 2013). Gregory and Wang (2010) found that if a company has increased free cash flow, it will generate a better return than a company with low free cash flow. In principle, the company's free cash flow is used to fund projects, pay debts, and is distributed to shareholders in the form of dividends (Dewi, 2016).

Research conducted by Wang (2010) ongoing public companies in Taiwan, free cash flow has a positive effect on firm value; this means that the higher its free cash flow, the better its performance. Other research conducted by Arfan (2013) and Andini and Wirawati (2014) found that free cash flow positively affects firm value. In contrast to Naini (2014), the results of free cash flow have no impact on firm value. Arieska and Gunawan (2011) state that free cash flow hurts firm value. The negative effect of free cash flow on firm value is due to shareholders' concerns that free cash flow will be used by managers to take opportunistic actions to enrich themselves.

Leverage is also one of the factors that can affect firm value. This is because Leverage is a funding policy related to the company's decision to finance the company. Companies that use debt are liable for interest expense and loan principal expense. The use of debt (external financing) has a considerable risk of debt non-payment, so debt needs to pay attention to the company's ability to generate profits (Prasetyorini, 2013).

Research conducted by Naini (2014) shows that Leverage harms firm value. This is in line with Kaviani and Biabani's (2012) research, which shows that Leverage hurts firm value. Novari and Lestari (2016) found that Leverage does not affect firm value. This means that companies in funding their assets tend to use their capital (internal financing), which comes from retained earnings and share money rather than debt. Adequacy of funds owned by the company to finance its assets obtained from its capital causes the company to reduce its debt proportion.

Based on the differences in the results of the above research, the researchers are interested in researching the title "The Effect of Return on Assets (ROA), Free Cash Flow (FCF) and Debt to equity ratio on Firm Value," An empirical study on Consumer Goods Industry companies listed on the Stock Exchange. Indonesian Securities for the period 2016- 2018.

\section{LITERATURE REVIEW Stakeholder Theory}

The concept of corporate social responsibility has been known since the early 1970s, which is generally known as stakeholder theory, which means a collection of policies and practices relating to stakeholders, values, compliance with legal provisions, community, and environmental respect, and the commitment of the business community to contribute in sustainable development. Stakeholder theory starts with the assumption that values are explicitly and undeniably part of business activities. Stakeholder theory says that companies are not entities that only operate for their interests but must provide benefits to their stakeholders. Thus, the existence of a company is strongly influenced by the support given by stakeholders to the company. Corporate social responsibility should go beyond maximizing profits for the interests of shareholders (stakeholders), but more broadly that the welfare that can be created by the company is not limited to the importance of shareholders, but also for the interests of stakeholders.

\section{Company Value}

The theory of the firm provides recognition that the company's goal is to maximize profits or the current value of the company. The establishment of the company must have a clear purpose. The amount of a company that is reflected through stock prices will undoubtedly be influenced by several factors, such as the stock price index, interest rates, and the company's fundamental conditions. The necessary condition is a condition related to the internal states of the company. Significant factors are closely related to company conditions, such as the financial condition of a company, which is reflected in the 
company's economic performance. If a company wants to do fundamental analysis, it requires the company's primary data derived from the company's financial statements, such as sales, dividends distributed, company profits, and so on.

According to Putra, the Price to Book Value (PBV) is the ratio used in determining the value of a company. PBV can assess the company in making value to the price of existing capital. If the PBV ratio increases, the company can be considered successful in creating corporate value and prosperity for investors in the company. If PBV has a tremendous amount, then the company will be highly valued by investors compared to the capital provided to the company.

\section{Return on Assets}

Return On Assets is a ratio that shows the results of the total assets used in the company (Kasmir 2014). ROA is a profitability ratio used to measure the company's effectiveness in generating profits by utilizing its total assets. The greater the ROA, the higher the company's ability to provide gains through the assets owned by the company and vice versa, the lower ROA can be caused by a large number of idle company assets, too much investment in inventory, excess banknotes, fixed assets operating below normal and others. Syardiana (2015) states that ROA is a ratio that shows a company's ability to generate net income using total assets. The greater the ROA results, the better the company's performance.

\section{Free Cash Flow (FCF)}

Free Cash Flow (FCF) or Free Cash Flow is one of the tools to measure a company's growth, financial performance, and health. Free Cash Flow represents the remaining cash from business operating activities that can be used for dividend payments, expansion, or debt repayment. The more Free Cash Flow value the company prints, the better. According to Brigham and Houston (2014), free cash flow is cash flow that is available to be paid to investors (shareholders and debt owners) after the company has invested in fixed assets, new products, and required working capital.

\section{Debt to Equity Ratio}

Debt to Equity Ratio is one of the leverage ratios that measure how much the company's operations are financed by debt than the company's operations sponsored by Equitas. This ratio shows how much the company depends on the creditors' funds compared to the owner's funds. In general, the creditor or prospective creditor requires information on how much the owner's funds as the basis for determining the level of creditor security. Low leverage ratios have a small risk of loss when the economy slumps and low profits when the economy surges.

\section{Past Research}

Lubis, Sinaga, and Sasongko, conducted research with profitability, capital structure, and liquidity variables on firm value. With the results of profitability research having a positive and significant effect on firm value, capital structure is negatively related and not significantly on firm value, and liquidity is positively related and insignificant on firm value.

Hidayah the effect of Investment Opportunity Set (using CAPBVA price proxy and MVBVE Investment Proxy) and managerial ownership on firm value The results of this study indicate that the independent variable is IOS (CAPBVA and MVBVE) have a significant effect on firm value, while managerial ownership variables have no significant impact on firm value.

Bintara and Tanjung. Analysis of Fundamental Factors on Stock Return, explains that Return on Assets, Current Ratio, Debt to Equity, and Price Earning Ratio affect the value of the company proxied by Stock Return. In contrast, PBV does not affect the value of the company.

Tanjung and Wahyudi. Analysis of the Effect of Disclosure of Sustainability Report, Economic Value Added, and Other Fundamental Factors of Companies on Company Value explains that Debt to Equity and Price Earning Ratio affect the firm's value.

Moeljadi and Supriyati conducted a study of the factors that influence firm value in manufacturing companies in Indonesia. The research variables used are Corporate Social Responsibility (CSR), Corporate Governance (CG), company size, profitability, and its effect on firm value. The results of his research show that a large size company will have a significant corporate amount, good profitability indicates good company value, and CSR and good corporate CG affect the company's value.

\section{Framework}

Based on the periodization chosen in this study and the previous description, the theoretical framework of this research is described as follows:

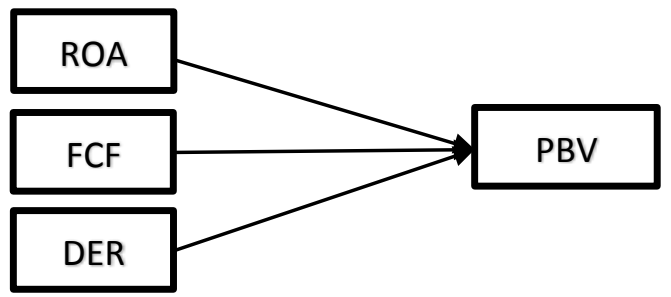

Figure 1. Framework 


\section{Research Hypothesis}

Based on the theory and thought framework previously described, the following research hypothesis can be formulated:

H1: Return on Assets affects Firm Value.

H2: Free Cash Flow affects Firm Value.

H3: Debt to Equity Ratio affects Firm Value.

\section{Research and Operational Variables Company Value}

The company's value is proxied using Price to Book Value (PBV). This ratio is used to measure the level of stock prices, whether overvalued or undervalued. The lower the PBV value of a stock, the stock is categorized as undervalued, which is very good for long-term investment. PBV is a ratio that shows the results of the comparison between the market price per share with the book value per share. These measurements are formulated as follows:

\section{Return On Assets}

$$
P B V=\frac{\text { Price per share }}{\text { Book value per share }}
$$

Return On Assets is a ratio that shows how much the contribution of the company's assets in creating profits clean. Investors will have more confidence in companies that can manage their assets correctly, providing gain to them. This variable is measured by calculating the comparison of the results between total net income and total assets the company is formulated as follows.

\section{Free Cash Flow}

$$
R O A=\frac{\text { Net income }}{\text { Total Assets }}
$$

Free cash flow is cash flow that is available to be paid to investors (shareholders and owners debt) after the company invests in fixed assets, new products, and the working capital needed for maintaining ongoing operations. Free cash flow is a reference, the extent to which the company can provide profit sharing to investors. The higher the free cash flow, the greater the company's value and, of course, the more attractive to investors. The formula measures this variable asfollows:

\section{Debt to Equity Ratio}

$$
F C F=\frac{\text { Free Cash Flow }}{\text { Total Assets }}
$$

Debt to Equity Ratio, namely the ratio between total debt with total equity. Debt to Equity Ratio shows how much shareholders own the company's assets compared to assets owned by creditors or creditors. The following formula measures this variable:

$$
D E R=\frac{\text { Total Liabilities }}{\text { Total Shareholder'sEquity }}
$$

\section{Population and Sample}

This study's population were Consumer Goods Industry companies listed on the Indonesia Stock Exchange for the period 2016-2018. Selected by researchers based on certain qualities and characteristics, so that obtained 40 companies.

The type of sample selection in this study is using a purposive sampling method, namely the sampling technique, with specific considerations. The considerations in sampling, namely:

1.) Consumer Goods Industry companies listed on the Indonesia Stock Exchange for the period $2016-2018$

2.) Consumer Goods Industry companies that do not present complete data according to the needs of researchers.

\section{RESULTS AND DISCUSSION Descriptive statistics}

The results of data processing can be seen from the descriptive statistics below:

Table 1. Descriptive Statistics

Descriptive Statistics

\begin{tabular}{lc|c|c|c|c} 
& $\mathbf{N}$ & Min & Max & Mean & Std. Dev \\
\hline PBV (Y) & 120 & -.16 & 90.67 & 5.86 & 12.83 \\
\hline ROA (X1) & 120 & -2.64 & .92 & .05 & .28 \\
\hline FCF (X2) & 120 & -.27 & 1.27 & .06 & .18 \\
\hline DER (X3) & 120 & -1.59 & 11.35 & .95 & 1.26 \\
\hline Valid N & 120 & & & & \\
\hline \multicolumn{2}{l|l}{ Source: Results of SPSS data processing 22 }
\end{tabular}

Based on the descriptive statistical test results in the table above, it can be explained

as follows :

1. The variable Price Book Value (PBV) has a minimum value of -0.16 , and the maximum amount is 90.67. Average company value in the Consumer Goods Industry industry in 2016 -
2018, namely 5.86, which means the average shares of the Consumer Goods Industry company 2016 - 20185.86 times more than its book value. A company with a PBV ratio $<1$, it is considered as a low-priced stock, whereas a PBV ratio $>1$ is deemed to be expensive stocks. While the standard deviation value in the sample 
is 12.83 , the mean cost is smaller than the standard deviation, indicating that the result is unfavorable because it reflects a very high variation. The spread of data shows abnormal results and causes bias.

2. The variable Return on Assets (ROA) has a minimum value of -2.64 and a maximum value of 0.92 with an average cost of 0.05 while the standard deviation is 0.28 with a total of 120 data. The average ROA value of the Consumer Goods Industry companies in this year 20162018, which is 0.05, which means that the average consumer goods industry company earns a profit of 0.05 times the total assets owned.

3. The Free Cash Flow (FCF) variable has a minimum value of -0.27 and a maximum value of 1.27 with an average of 0.06 while the standard deviation is 0.18 with 120 data.The average FCF value of the Consumer Goods Industry company in 2016 - 2018, which is 0.06 or $6 \%$, which means that on average, Consumer Goods Industry companies have free cash flow that can be distributed to investors by $6 \%$ of total assets owned typically.

4. The debt to equity ratio variable has a minimum value of -1.59 and a maximum value of 11.35 with an average of 0.95 , which means that the average consumer goods industry company has a debt of 0.95 times its total equity.

\section{Classic Assumption Test}

The classic assumption test is carried out so that the regression model in the research is significant and representative. In the multiple regression analysis, it is necessary to avoid any standard assumption deviation so that problems do not arise in its use. The basic assumption is that the data is normally distributed; there is no heteroscedasticity, multicollinearity, and autocorrelation. Based on the normality test in this study, the Asymp value model. Sig. (2tailed) $=0.200$, then according to the provisions of $0.200>0.05$, the residual value is normal. Then the data in the model can be said to be normally distributed. Multicollinearity test which shows that the VIF value is below 10, and the tolerance value is above 0.10 . From the results of these tests, it can be concluded that the regression model does not have multicollinearity problems.
Heterokedatisitas test shows that there was no heteroscedasticity. This can be seen from the probability of its significance (Sig. Value) on each independent variable above the $5 \%$ confidence level or 0.05 . So it can be concluded that the regression capital does not contain heteroscedasticity. The autocorrelation test in this study used the autocorrelation test using the Durbin-Watson (DW) test. The results of the autocorrelation test data obtained no positive or negative autocorrelation, or it can be concluded that there is no autocorrelation.

\section{HYPOTHESIS TESTING RESULTS} Determinant Coefficient Test Results (R2) According to Ghozali, the coefficient of determination essentially measures how far the model's ability to explain variations in the dependent variable. The ratio of determination aimed at $R^{2}$ from the regression model is used to determine the dependent variable that can explain the magnitude of the variability of the dependent variable. The coefficient of determination test results is known that the $\mathrm{R}$ Square value of $22 \%$, this shows that the variation in firm value can be explained by changes in return on assets, free cash flow and debt to equity by $22 \%$. While the remaining $78 \%(100 \%-22 \%)$ is solved or influenced by other factors not examined in this study.

\section{Model Feasibility Test Results (Test F)}

According to Ghozali, F statistical test is basically to show whether all independent variables are included. Based on the table above, it is known that the calculated $F$ value of 16.637 with a probability of $0,000<0.05$; this indicates that the model used in this study is feasible. So in this regression model, it can be concluded that the variables of in return on assets, free cash flow and debt to equity affect the value of the company.

\section{Partial Hypothesis Testing (t test)}

The $t$ test is used to determine whether the independent variable partially affects the dependent variable, with a significance level of $5 \%$. If the sig value is greater than 0.05 , then $\mathrm{H} 0$ is accepted. If the sig value is less than 0.05 then $\mathrm{H} 0$ is rejected and $\mathrm{Ha}$ is accepted. The results of the $\mathrm{T}$ test are as follows: 
Table 2. Hypothesis Testing ( $\mathrm{t}$ test)

\begin{tabular}{|c|c|c|c|}
\hline Model & $\begin{array}{l}\text { Coefficients } \\
\text { Standardized } \\
\text { Coefficients } \\
\text { Beta }\end{array}$ & $T$ & Sig. \\
\hline (Constant) & & .216 & .829 \\
\hline ROA (X1) & .584 & 4.192 & .000 \\
\hline $\mathrm{FCF}(\mathrm{X} 2)$ & -.160 & -1.165 & .246 \\
\hline DER (X3) & .198 & 2.327 & .022 \\
\hline
\end{tabular}

a. Dependent Variable: PBV

Source: Results of SPSS data processing 22

Based on the test results in table 4.9, the following conclusions can be drawn:

1. Ha1: Effect of Return On Assets (ROA) on firm value. The t-test result shows that the significance value is 0.000 ( $\operatorname{sig}<0.05$ ). This indicates that the Return On Assets (ROA) affects firm value. So that the hypothesis Hal is accepted.

2. Ha2: Effect of Free Cash Flow (FCF) on firm value. The t-test results show that the significance value is 0.246 (sig > 0.05). This indicates that Free Cash Flow (FCF) does not affect firm value. So that the hypothesis $\mathrm{Ha} 2$ is rejected.

3. Ha3: Effect of Leverage (DER) on firm value. The t-test results show that the significance value is 0.022 ( sig $<0.05)$. This indicates that Leverage (DER) affects firm value. So that the hypothesis Ha3 is accepted.

\section{Multiple Linear Regression Analysis}

To test whether or not the effect of Return On Assets (ROA), Free Cash Flow (FCF), and Leverage (DER) on Firm Value, multiple linear regression is used. The results of various linear analysis tests can be seen in the following:

$$
\mathrm{PBV}=0.351+51.920 \mathrm{ROA}-11.514 \mathrm{FCF}+2.196 \mathrm{DER}+\mathrm{e}
$$

Table 3 Research Model

\begin{tabular}{|c|c|c|c|c|}
\hline \multicolumn{5}{|c|}{ Coefficients $^{a}$} \\
\hline & \multicolumn{2}{|c|}{$\begin{array}{l}\text { Unstandardized } \\
\text { Coefficients }\end{array}$} & \multirow[b]{2}{*}{$\mathrm{t}$} & \multirow[b]{2}{*}{ Sig. } \\
\hline Model & $\mathrm{B}$ & $\begin{array}{c}\text { Std. } \\
\text { Error }\end{array}$ & & \\
\hline 1 (Constant) & .351 & 1.621 & .216 & .829 \\
\hline ROA (X1) & 51.920 & 12.387 & 4.192 & .000 \\
\hline FCF (X2) & -11.514 & 9.881 & -1.165 & .246 \\
\hline DER (X3) & 2.196 & .944 & 2.327 & .022 \\
\hline a. Dependent & PBV & & & \\
\hline
\end{tabular}

The explanation of the multiple linear regression equation is:

1. Constant $\mathrm{a}=0.351$, which means that if the independent variable, namely Return On Assets (ROA), Free Cash Flow (FCF), and Leverage (DER) is considered constant or zero, then the dependent variable Firm Value (PBV), has a value of 0.351 unit.

2. The Return On Assets (ROA) regression coefficient is 51,920 units, which means that if the ROA value increases by one company, then the firm value (PBV) will increase by 51,920 units. The ROA regression coefficient is positive, which means a unidirectional relationship between ROA and PBV. The higher the ROA value, the higher the PBV value. The ROA variable gets sig. 0.00 results that are smaller than 0.05 so that the ROA variable is declared to have a significant positive effect on firm value.

3. The Free Cash Flow (FCF) regression coefficient is $-11,514$ units, which means that if the FCF value increases by one team, the firm value (PBV) will decrease by $-11,514$ units. The FCF regression coefficient is negative, which means a contradictory relationship between FCF and PBV. The higher the FCF value, the lower the PBV value. The FCF variable gets the sig. 0.246, 
which is more significant than 0.05 , so that the FCF variable is declared to have no significant effect on firm value.

4. The Leverage regression coefficient (DER) is 2,196 units, which means that if the DER value increases by one team, the firm buys (PBV) will increase by 2,196 units. The DER regression coefficient is positive, which means a unidirectional relationship between DER and PBV. The higher the DER value, the higher the PBV value. The DER variable gets the sig. 0.022 , which is smaller than 0.05 , so that the DER variable is stated to have a significant positive effect on firm value.

\section{DISCUSSION OF RESEARCH RESULTS}

\section{Effect of Return On Assets on Firm Value}

The t-test calculation partially ROA variable obtains sig. 0.00 results that are smaller than 0.05 so that the ROA variable is declared to have a significant positive effect on firm value. This is in line with research conducted by Widiastari and Yasa (2018), Suwardika and Mustanda (2017), Pratama and Wirawati (2016), Triagustina, Sukarmanto, and Helliana (2015), Naini (2014), and Chen and Chen (2011). which states that profitability, as measured using Return On Assets (ROA), affects firm value because the effectiveness of managing existing assets will increase company profits. Thus, the company's ability to pay dividends will also be higher, and its stock price will increase company value.

However, this study contradicts the research conducted by Astriani (2014), which states that profitability using the ROA proxy has no effect on firm value. Profitability does not affect firm value because its profits are unstable from year to year and tend to fluctuate so that investors are not sure about the results the company will get in the future.

\section{Effect of Free Cash Flow on Firm Value}

The result of the t-test calculation partially ROA variable obtains sig. 0.246, which is greater than 0.05 , so that the FCF variable is declared to have no significant effect on firm value. This is in line with Widiastari and Yasa (2018) and Naini (2014), which states that Free Cash Flow does not affect firm value. The non-impact of Free Cash Flow on company value is due to shareholders' concerns that the free cash flow in the company will be used by managers to take opportunistic actions to enrich themselves. (Arieska and Gunawan, 2011). When a company has a high level of free cash flow, but no profitable projects are available, there will be a tendency for management to commit acts of misuse of free cash flow with opportunistic actions such as allocating inefficient resources and excessive consumptive behaviors where it is -this is not in line with the increase in company value but will burden the shareholders. Thus, free cash flow has no role in increasing company value.

However, this research contradicts research conducted by Sari (2016), Arfan (2013), Hadi, Javanshir, Oladi, Ghadiri, Moghaddam, and Mojarad (2013), and Wang (2010), which stated that Free Cash Flow (FCF) affects the value of the company. This is because companies with high free cash flow rates will have a greater return than companies with low free cash flow rates. The company's high performance will increase the company's value, which is manifested in the form of high returns through dividends, stock prices, or retained earnings to be invested in the future.

\section{Effect of Debt to Equity Ratio on Firm Value}

The result of the t-test calculation partially ROA variable obtains sig. 0.022 ( $\operatorname{sig}<0.05)$. This shows that Leverage (DER) affects firm value. So that the hypothesis Ha3 is accepted. This is in line with Naini (2014) research, Anisyah, and Purwohandoko (2017), which states that Leverage has a positive and significant effect on firm value. This is because companies with a level of leverage are required by creditors to supervise managers using their loan funds. A company with a low level of power will increase its disclosure because creditors prefer companies with a low leverage level. Companies that have a high level of leverage face an increased risk of corporate bankruptcy. If bankruptcy occurs, the creditor will be harmed because the company will reduce the disclosure level so that creditors do not assess the company negatively.

However, this study contradicts research conducted by Astriani (2014), which states that leverage does not affect firm value. Leverage does not affect firm value probably because managers have not used external sources of funds effectively, so leverage does not affect firm value. The trade-off theory states that debt will increase the value of the company but only up to a certain point. After passing that point, debt will decrease the company's worth because the increase in profit from the use of debt is not proportional to the rise in the costs of financial distress and agency conflicts. Leverage, which is proxied by debt to equity ratio, is a ratio used to measure a company's ability to meet all its liabilities. The level of debt to equity ratio will affect investors' judgment. The bigger the debt to equity ratio indicates, the greater the costs that must be incurred by the company to finance the deficit, as a result, the distribution of operating profit is more absorbed to pay off these long-term obligations so that the remaining profit for shareholders is getting smaller. 


\section{CONCLUSIONS AND RECOMMENDATIONS Conclusion}

After processing and testing carried out, regarding Return On Assets (ROA), Free Cash Flow (FCF), and Leverage (DER) on company value in Consumer Goods Industry companies listed on the Indonesia Stock Exchange for the period 2016 2018, the conclusions are drawn as The following: (1) Return On Assets (ROA) has an effect on firm value in the Consumer Goods Industry company for the period 2016-2018. (2) Free Cash Flow (FCF) has no impact on firm value in the Consumer Goods Industry company for 2016-2018. 3) Leverage (DER) affects company value in the Consumer Goods Industry company for the period $2016-2018$.

\section{Recommendations}

The Recommendations from the research to be conveyed are as follows: (1) For the management of the company, it is best to always evaluate the company's performance by optimizing the use of resources as well as possible to be able to realize the good corporate value and the company to increase the number of its assets. to fully support the company's operations. (2) Investors who wish to invest in Consumer Goods Industry companies are advised to pay attention to the value of the company's Return On Assets (ROA) and Leverage (DER) because Return On Assets (ROA) and Leverage (DER) affect firm value. The effectiveness of existing asset management will increase company profits. Thus, the company's ability to pay dividends will also be higher, and its stock price will increase company value. A company with a low level of leverage will increase its disclosure because creditors prefer companies with a low leverage level. Companies that have a high level of influence face an increased risk of corporate bankruptcy. If bankruptcy occurs, the creditor will be harmed because the company will reduce the disclosure level so that creditors do not assess the company negatively. (3) In this study, there are still shortcomings. Therefore, it is expected that further research examining firm value should use other factors. It involves the elements that belong to the company's financial performance and uses other factors such as macroeconomics and so on. (4) For future researchers, researchers should add to the vulnerable period used in conducting research and use different samples to be generalized to all companies in Indonesia.

\section{REFERENCES}

1. Agus, R. Sartono. (2010). Manajemen Keuangan Teori dan Aplikasi. Edisi keempat. Yogyakarta: BPFE.

2. Andini, Ni Wayan Lady; Wirawati, Ni Gusti Putu. (2014). Pengaruh Free Cash Flow pada Kinerja Keuangan dan Implikasinya pada Nilai
Perusahaan Manufaktur. E-Jurnal Akuntansi, [S.1], p. 107-121, ISSN 2302-8556.

3. Anisyah dan Purwohandoko. (2017). Pengaruh Profitabilitas, Leverage, ukuran Perusahaan dan Struktur Modal terhadap Nilai Perusahaan pada sektor Pertambangan yang terdaftar pada bursa efek Indonesia periode 2010 - 2015. Jurnal Manajerial Bisnis, [S.I.] V.1 N.01, P.34-46. ISSN 2597-503X.

4. Arfan, Muhamad. (2013). Nilai Perusahaan Dalam Kaitannya Dengan Arus Kas Bebas Dan Pertumbuhan Perusahaan. Jurnal Telaah dan Riset Akuntansi Universitas Syiah Kuala, 6(1); $h: 14-30$

5. Arieska, Metha dan Barbara Gunawan. (2011). Pengaruh Aliran Kas Bebas dan Keputusan Pendanaan Terhadap Nilai Pemegang Saham dengan Set Kesempatan Investasi dan Dividen Sebagai Variabel Moderasi. Jurnal Akuntansi dan Keuangan 13(1); h:13-23.

6. Astriani, Eno Fuji. (2014). Pengaruh Kepemilikan Manajerial, Leverage, Profitabilitas, Ukuran Perusahaan dan Investment Opportunity Set terhadap Nilai Perusahaan", Jurnal Akuntansi.

7. Bintara, R., Tanjung ,P. R. S. (2019). Analysis of Fundamental Factors on Stock Return, International Journal of Academic Research in Accounting, Finance and Management Sciences, 9(2): 49-64

8. Brigham, Eugene F dan Joel F Houston. (2013). Dasar-Dasar Manajemen Keuangan, Penerjemah Yulianto Ali, Edisi 11, Edisi Indonesia, Buku 2, Jakarta: Salemba Empat.

9. Brigham, Eugene F dan Joel F Houston. (2014). Dasar-Dasar Manajemen Keuangan, Penerjemah Yulianto Ali, Edisi 11, Edisi Indonesia, Buku 1, Jakarta: Salemba Empat.

10. Chen, Li-Ju, and Chen, Shun-Yu. (2011). The Influence of Profitability on Firm Value With Capital Structure as The Mediator and Firm Size and Industry as Moderators. Investment management and Fiancial Innovations, 8(3). Pp:121-129

11. Dewi, Ayu Sri Mahatma dan Ary Wirajaya . 2013 ."Pengaruh Struktur Modal, Profitabilitas dan Ukuran Perusahaan terhadap Nilai Perusahaan". E-Journal Akuntansi Universitas Yudayana, 358-372.

12. Dewi, Dian Masita. 2016. Pengaruh Likuiditas, Leverage, Ukuran Perusahaan Terhadap Kebijakan Dividen Tunai Dengan Profitabilitas Sebagai Variabel Intervening. Jurnal Bisnis dan Ekonomi (JBE), Maret 2016, Vol. 23, No. 1. Hal. $12-19$.

13. Garmayuni, Rindu Rika. (2015). The Effect of Intangible Asset, Financial Performance and Financial Policies on The Firm Value. International Journal of Scientific and Technology Research, 4(1), pp: 202-212.

14. Hadi, javanshir, Oladi Bashir, Ghadiri Moghaddam Abolfazl dan Mojarad Maryam. (2013). The Relationship Between Free Cash Flow, Accruls and Firm Value. World of Sciences 
Journal. Vol.1, Issue. 12: 26-33, ISSN: 23073071 .

15. Hemastuti,C.P. (2014). Pengaruh Profitabilitas, Kebijakan Dividen, Kebijakan Hutang, Keputusan Investasi, dan Kepemilikan Insider Terhadap Nilai Perusahaan. Jurnal Ilmu \& Riset Akuntansi. Vol.3. No.4.

16. Hidayah, N. (2015). Pengaruh Investment Opportunity Set (Ios) Dan Kepemilikan Manajerial Terhadap Nilai Perusahaan Pada Perusahaan Property Dan Real Estat Di Bursa Efek Indonesia. Jurnal Akuntansi, 19(3), 420432.

17. Husnan, Suad. (2014). Manajemen Keuangan Teori dan Penerapan (Keputusan Jangka Panjang). Edisi Keempat. Yogyakarta: BPFE.

18. Kasmir. (2014). Analisis Laporan Keuangan, Edisi Satu, Cetakan Ketujuh. Jakarta: Raja Grafindo Persada.

19. Kaviani, Meysam \& Biabani, Shaer. (2012). Study of and Explain the Relationship between the Financial Leverage and New Performance Metrics (EVA, MVA, REVA, SVA and CVA) Evidence from Automotive Industry Tehran Stock Exchange. Journal of Risk and Diversification. ISSN 1986- 4337 Issue 4.

20. Lubis, I. L., Sinaga, B. M., \& Sasongko, H. (2017). Pengaruh Profitabilitas, Sruktur Modal, Dan Likuiditas Terhadap Nilai Perusahaan. Jurnal Aplikasi Bisnis Dan Manajemen, 3(3), 458-465.

21. Naini, Dwi Ismawati. (2014). Pengaruh Free Cash Flow dan Kepemilikan Institusional Terhadap Kebijakan Hutang dan Nilai Perusahaan. Jurnal Ilmu dan Riset Akuntansi.

22. Nirmala, A., Moeljadi, M., \& Andarwati, A. (2016). Pengaruh Ukuran Perusahaan, Profitabilitas, Pertumbuhan Penjualan dan Kepemilikan Manajerial terhadap Struktur Modal dan Nilai Perusahaan Manufaktur di Indonesia (Perspektif Pecking Order Theory). Jurnal Aplikasi Manajemen, 14(3), 557-566.

23. Noerirawan, Ronni, dkk. 2012. Pengaruh Faktor Internal dan Eksternal Perusahaan Terhadap Nilai Perusahaan. Jurnal Akuntansi Vol.1 No. 2. hal. 4.

24. Novari, Putu Mikhy; Lestari, Putu Vivi. (2016). Pengaruh Ukuran Perusahaan, Leverage dan Profitabilitas terhadap Nilai Perusahaan pada sektor Properti dan Real Estate. E-Jurnal Manajemen, [S.l.], v. 5, n. 9. ISSN 2302-8912.

25. Prasetyorini, Bhekti Fitri. (2013). Pengaruh Ukuran Perusahaan, Leverage, Price Earning Ratio dan Profitabilitas terhadap Nilai Perusahaan. Jurnal Ilmu Manajemen, 1(1), h: 183-196

26. Pratama dan Wirawati. (2016). Pengaruh Struktur Modal dan Profitabilitas terhadap Nilai Perusahaan dengan Kepemilikan Manajerial Sebagai Pemoderasi. ISSN:2302---8556 E-Jurnal Akuntansi Universitas Udayana Vol.15.3.

27. Sari, Аyи Kurnia. (2016). Pengaruh Free Cash Flow dan Ukuran Perusahaan terhadap Nilai Perusahaan yang terdaftar pada Bursa Efek
Indonesia. Jurnal Ilmiah "INTEGRITAS”. Vol. 2, No. 1, 2016.

28. Sudiani, N., \& Darmayanti, N. (2016). Pengaruh Profitabilitas, Likuiditas, Pertumbuhan, Dan Investment Opportunity Set Terhadap Nilai Perusahaan. E-Jurnal Manajemen Universitas Udayana, 5(7), 4545-4547.

29. Suwardika, I Nyoman Agus; Mustanda, I Ketut. (2017). Pengaruh Leverage, Ukuran Perusahaan, Pertumbuhan Perusahaan dan Profitabilitas terhadap Nilai Perusahaan pada Perusahaan Properti. E-Jurnal Manajemen, [S.1], V.6, N.3, P.1248-1277.

30. Syardiana, G., Rodoni, A., dan Putri, Z. E. (2015). Pengaruh Investment Opportunity Set, Struktur Modal, Pertumbuhan Perusahaan dan Return On Asset terhadap Nilai Perusahaan. Akuntabilitas, Vol. VIII No. 1, P-ISSN: 1979858X, HLM 39-46.

31. Tanjung, P.R.S., Wahyudi, S.M. (2019). Analysis the Effect Disclosure of Sustainability Report, Economic Value Added and Other Fundamental Factors of Companies on Company Value, International Journal of Academic Research in Accounting, Finance and Management Sciences, 9(2): 237-249

32. Tanjung, Putri Renalita Sutra. 2020. Effect of Corporate Social Responsibility Disclosure, Good Corporate Governance Implementation, and Profitability on Corporate Value (Asean Country Study 2016-2018). Saudi Journal of Business and Management Studies. Saudi Journal of Business and Management Studies

33. Triagustina, Sukarmanto dan Helliana (2015). Pengaruh Return On Asset (ROA) Dan Return On Equity (ROE) terhadap Nilai Perusahaan. Prosiding Akuntansi. Vol.1, No. 2

34. wangWang, Goerge Yungchih. (2010). The Impact of Free Cash Flow and Agency Cost on Firm Performance. Journal Service Science \& Management, 3, 408-418

35. Widiastari, Putu Ayu; Yasa, Gerianta Wirawan. (2018). Pengaruh Profitabilitas, Free Cash Flow, dan Ukuran Perusahaan Pada Nilai Perusahaan. E-Jurnal Akuntansi, [S.l.], p. 957981. 